\title{
Development of Low Cost Solar Rack Dryer and Comparative Biochemical Quality Evaluation of Anchovies (Stolephorus commersonii) Dried in Sun and Solar Rack Dryer
}

\author{
S. Tanuja*, C. S. Mhatre, G. Mohanty, E. Rout, P. Rout and S. K. Srivastava \\ ICAR-Central Institute for Women in Agriculture, Plot No. 50-51, Mouza - Jokalandi, P.O. - \\ Baramunda, Bhubaneswar - 751003, Odisha, India \\ *Corresponding author
}

\section{Keywords}

Low cost solar rack dryer, Anchovies, Biochemical quality

Article Info

Accepted:

05 February 2020 Available Online: 10 March 2020

A B S T R A C T

A low cost solar rack dryer was fabricated with an aim to popularise hygienic drying of fish among fisherwomen and it was evaluated for drying of Anchovy (Stolephorus commersonii) at Central Institute for Women in Agriculture, Bhubaneswar, Odisha. It was observed that on an average the solar dryer attained $17.5 \%$ higher temperature than the ambient temperature. Within a total drying time of $13 \mathrm{~h}$, the moisture content of the fish reduced from about $81.97 \%$ to $28.87 \%$ and $34.43 \%$ by the solar rack dryer and open sun drying respectively. There was significant differences in the moisture content, crude protein and ash content of fish dried using the two methods with the solar rack dried fishes significantly faring better. The values of biochemical quality indicators like Total Volatile Base Nitrogen and Peroxide value were significantly low in solar rack dried fishes indicating a longer shelf life of these fishes. Hence it can be concluded that wide scale dissemination of the low cost solar rack dryer among the coastal fisherwomen population will help them to earn better returns in their occupation through sale of the hygienic dry fish.

\section{Introduction}

Dry fish is referred to as poor man's protein. Dry fish segment constitutes $20 \%$ of the total fish production in India. Marine fish drying is the most common form of processing throughout the coastal belt of India and is the cheapest means of fish value addition. The economic returns from fish drying still remains low because of the unhygienic drying practices, lack of adoption of scientific protocol for curing, improved drying practices 
and packaging. Improved technologies for drying include the use of mechanical dryers or solar dryers. The initial investment in mechanical drying systems is high but dried fish is stable for extended periods of storage and is safe for consumption throughout storage (Reza et al., 2009; Dagne et al., 2016). The non adoption of these improved technologies by fisherwomen in developing countries like India is because of the high capital investment involved. As a result sun drying is still the simplest and economical method of fish preservation practiced all over the world. But sun drying has many limitations, such as extended periods of drying which affects the keeping quality, inability to dry during rainy season or cloudy weather conditions, non suitability to high humid regions etc. Because of these reasons sun drying of fish often results in low quality, insect infested and contaminated product. Hence development and popularisation of dryers which are cheap yet will serve the purpose of hygienic and faster drying of fish is the need of the hour.

Methods of drying vary with the species used. The ultimate objective is the reduction in moisture within the range of $10-35 \%$. The effect of different drying methods on different fish species have been studied (Immaculate $e t$ al., 2012; Hasan et al., 2016; Rasul et al., 2018). The present paper deals with the development of a cost effective solar rack dryer to be popularised among fisherwomen for hygienic drying of fish and to compare the drying characteristics, nutritional and biochemical characteristics of Anchovy (Stolephorus commersonii) dried in the solar rack dryer and in open sun.

\section{Materials and Methods}

\section{Dryer specifications}

A suitable size natural-convention type solar dryer for drying fish was designed for the humid climate condition of Odisha state of India (Table 1). This natural convection type solar dryer was designed to bring down the moisture content of fish from about $80 \%$ to $25 \%$.

\section{Design procedure}

Design of the solar rack dryer was done according to Jhajharia and Seveda (2012) with some modifications. The size of the dryer was determined as a function of the drying area needed per kilogram of fresh fish. The drying temperature was established as a function of the maximum limit of temperature which the fresh fish may support.

The mass of water to be removed during drying, $\mathrm{M}_{\mathrm{w}}, \mathrm{kg}$,

$\mathrm{M}_{\mathrm{W}}=\frac{\frac{m i-m f}{100-m f}}{\mathrm{XW}}$

The mass of water removed per hour $\mathrm{m}_{\mathrm{w}}$, $\mathrm{kg} / \mathrm{h}$,

$\mathrm{m}_{\mathrm{w}}=\frac{\mathrm{Mw}}{\mathrm{td}}$

The total energy required Q kcal,

$\mathrm{Q}=\mathrm{W}^{*} \mathrm{C}_{\mathrm{p}} *\left(\mathrm{~T}_{\mathrm{d}}-\mathrm{T}_{\mathrm{a}}\right)+\left(\mathrm{M}_{\mathrm{w}} * \lambda\right)$

The energy required per hour $\mathrm{Q}_{\mathrm{t}}, \mathrm{kcal} / \mathrm{h}$,

$\mathrm{Q}_{\mathrm{t}}=\frac{\frac{Q}{\mathrm{td}}}{}$

Collected area required, Ac, $\mathrm{m}^{2}$,

$\mathrm{A}_{\mathrm{c}}=\frac{\mathrm{QtX100}}{\text { It *n! }}$

\section{Construction of the solar dryer}

The solar dryer (Fig. 1) was designed as per the above procedure. The required area of 
collector be $3.00 \mathrm{~m}^{2}$, hence the length and width of dryer was taken $2.45 \mathrm{~m}$ and $1.22 \mathrm{~m}$ respectively. The height of the dryer was kept 1.52 for ease of loading and unloading by women. Slope was also provided to the dryer roof to avoid pooling of water or debris on top of it.

The standard components solar rack dryer are frame structure, covering material and drying trays. These materials used for their construction are affordable and easily available in the local market.

According to the material for construction (Either mild steel or stainless steel), the cost of construction ranges from Rs 8000 to Rs $12000 /$ dryer.

Frame structure: The frame structure consists of base frame and doors. The mild steel angle of $25 \times 25 \times 3 \mathrm{~mm}$ was used in the fabrication of base frame of the solar dryer. Mild steel flat of $20 \times 3 \mathrm{~mm}$ was used in the fabrication of supporting frame of the solar dryer and to hold trays. Doors were provided for ease of loading and unloading.

Drying trays: The drying trays were contained inside the drying chamber and were constructed from wire mesh and wood, it allowed drying air to pass through the fish. Total 12 no. $\mathrm{s}$ of trays of dimensions (LXBXH:: 1.2 X 0.52 X 0.75) can fit inside the dryer.

Covering material: The transparent 200 micron UV stabilized plastic sheet was fixed on the four side of the frame for the interception of solar energy. But the bottom and back sides were fixed by black colored plastic. It was fasten to the frame using fastening strips.

Ventilation: 4 chimneys were provided for ventilation..

\section{Performance evaluation}

Anchovy fish (Stolephorus commersonii), locally known as kokali, was considered for study in the open sun drying and the natural convention solar rack dryer. The fresh fish obtained from local markets of Bhubaneswar were bought in iced condition to the laboratory, gutted and washed with clean water. The initial moisture content of the sample was determined by drying at $105^{\circ} \mathrm{C}$ for 6 hours and was observed to be $81.97 \pm$ $0.31 \%$. The fish was salted (1:8:: Salt: fish) and kept for $24 \mathrm{hrs}$ in plastic trays covered with polythene. The polythene was given holes. After $24 \mathrm{hrs}$ the fish was rinsed in clean water to remove the excess salt and the water was drained off. The fishes were divided into 2 batches. Each batch was further divided in 3 replications of $200 \mathrm{~g}$ each. One batch was dried in open and the other in the developed solar rack dryer.

A wire mesh tray was used to dry the fish in open sun as well as solar rack dryer. The fish were arranged in a single layer over the mesh on nylon net. The dryer was properly oriented for maximum sunlight reception. The experiment was conducted in the month of June, 2019 under the climatic condition of Bhubaneswar, Odisha, India.

\section{Proximate and biochemical analysis}

Samples were drawn from each lot in predetermined intervals to estimate the moisture content and thence the drying rate. Once the weight got stabilised, the samples were packed in HDPE Polythene pouches and sealed till further analysis. The proximate composition analysis was done according to AOAC (2000) All the chemicals used in the analysis were of analytical grade and supplied by Himedia, India. Moisture was estimated by drying in a hot air oven, fat by the ether extraction and crude protein by the 
Microkjeldahl method and ash was determined by using Muffle furnace. The biochemical parameters of The Total volatile base nitrogen (TVB-N) values were estimated by the Conway micro diffusion method (Conway, 1950). Free fatty acid was estimated from the chroloform extracts of the sample according to AOAC (2000). Peroxide value (PV) of dried anchovy was estimated by a titrimetric method (Yildiz et al., 2013)

\section{Statistical analysis}

Data sets were analysed parameter wise using Analysis of Variance (ANOVA). The data were statistically analysed by statistical package SAS 9.3. The differences between the experimental groups were considered significant at a level of $\mathrm{P}<0.05$.

\section{Results and Discussion}

\section{Drying characteristics}

As expected in the month of June, when monsoon initiates in Odisha, the weather was cloudy and humidity was high during the time of experiment. Hence the process of drying was spread over 4 consecutive days and different time of day owing to intermittent bouts of clouds and rain. The temperature for open condition ranged from 44 to $29^{\circ} \mathrm{C}$, while for solar dryer it ranged from 47 to $28^{\circ} \mathrm{C}$ throughout the test period. The ambient relative humidity ranged from 93 to $49 \%$ and for solar dryer is was between 84 to $44 \%$. The solar radiation for the duration was as low as $126 \mathrm{~W} / \mathrm{m}^{2}$ and as high as $773 \mathrm{~W} / \mathrm{m}^{2}$. Hence the moisture loss was recorded at one hour interval from 9-17 $\mathrm{h}$ as and when the ample sunshine or clear sky was available, till the samples no longer showed reduction in weight. The details of the weather condition are given in Table 2.

It was observed that with an increase in drying time, the rate of moisture removal was decreasing (Fig 2). This is in concurrence with the findings of Pathare and Jain (2007). The fish was dried to a constant moisture content of $28.89 \pm 0.31 \%$ in 13 hours in solar dryer, where in the same time the moisture content was reduced to only $34.43 \pm 0.32 \%$ in fish dried in open condition. There was no further weight reduction observed in the fish in the open condition. Thus, the dryer gives desirable moisture content in lower time as compared to the open condition, saving drying time.

\section{Proximate composition}

The moisture content was significantly lesser $(p<0.05)$ in solar dried fish than the open dried fish (Table 3). This could be because of the comparatively elevated temperatures and lower relative humidity inside the dryer. This is advantageous as higher moisture content is one of the accelerants for microbial and fungal growth in dried fish. The crude protein and ash content was significantly $(\mathrm{p}<0.05)$ higher in solar dried fish. This is because of the significant reduction in moisture content of the fish which results in aggregation of other proximate parameters. Several authors have reported the inverse relationship of moisture and other proximate parameters in dried fish (Shrivastava et al., 1974; Relekar et al., 2014).

Usually open dried fish has a significantly higher ash content because of deposition of dust and dirt particles on the fish (Immaculate et al., 2012; Rasul et al., 2018). In the present study, the inverse condition occurred probably because of settling down of dust particles by the intermittent rains in the month of June in Odisha. The lowest lipid content was observed in the dried fish produced by the open drying method, which might be due to comparatively higher oxidation of lipids caused by the uninhibited exposure to the sun., 


\section{Biochemical quality}

The total volatile bases in fish tissues include ammonia, monomethyl amine, dimethyl amine, and trimethyl amine etc. which gets accumulated due to bacterial decomposition of fish. The increase in these volatile bases leads to deterioration of odour and flavour in fish. The average TVB-N values of the dried anchovy was $50.92 \mathrm{mg} / 100 \mathrm{~g}$ and 76.29 $\mathrm{mg} / 100 \mathrm{~g}$ (Table 3) for solar dried and open dried fish respectively, which is much lower than the recommended value (100-200 $\mathrm{mg} / 100 \mathrm{~g}$ of muscle) for different dried and salted fish products (Connell, 1995). The fishes dried in open are prone to all sorts of contamination like environmental, contamination by pest or animals. The significantly higher $(\mathrm{p}<0.05)$ TVBN content in open dried fishes shows the faster deterioration of quality by traditional drying. Abraha et al., (2017) has reported a much lesser TVBN content of $20.12 \mathrm{mg} \%$ in dried anchovies. This may be because of the fact that TVBN in dry fish will also depend upon the initial quality of fresh fish.

Peroxide value is commonly used to assess rancidity development by oxidation of fats. As per Sankar et al., (2013), the fat content of S.commersonii ranged between 1.25 to $2.41 \%$ which puts it under the category of low to medium fatty fish. Fat oxidation is one of the factors which affects the quality and shelf life of dry cured fish especially those of high and medium fatty fishes. It has been reported that the peroxide value of herring (Clupea pallasii) lipids $(5.52-11.86 \mathrm{meq} / \mathrm{kg})$, a fatty fish increased significantly during the drying period (Shah et al., 2009).

Table.1 Assumptions and conditions for designing of solar rack dryer

\begin{tabular}{|c|c|}
\hline Items & Conditions/ Assumptions \\
\hline Location & $\begin{array}{l}\text { Bhubaneswar } \\
\left(20^{0} 16^{\prime} \mathrm{N} 85^{0} 50^{\prime} \mathrm{E}\right)\end{array}$ \\
\hline Product dried & Anchovy Fish \\
\hline Drying Period & June 2019 \\
\hline Initial moisture content (wb, \%) & 80 \\
\hline Final Moisture content (wb, \%) & 25 \\
\hline Loading Capacity, kg & 5 \\
\hline Assumed drying time, hrs & 24 \\
\hline Global solar radiation, $\mathrm{kWh} / \mathrm{m}^{2}$ & 3.72 \\
\hline Sunshine hours per day , hrs & 4.7 \\
\hline
\end{tabular}

Table.2 Weather parameters during the experiment of drying of Anchovy (S. commersonii)

\begin{tabular}{|c|c|c|c|c|c|c|c|c|c|c|}
\hline \multirow[t]{3}{*}{ Particulars } & \multicolumn{4}{|c|}{ Temperature, ${ }^{\circ} \mathbf{C}$} & \multicolumn{4}{|c|}{ RH, \% } & \multicolumn{2}{|c|}{ Solar Insolation, $\mathrm{W} / \mathrm{m}^{2}$} \\
\hline & \multicolumn{2}{|c|}{ dryer } & \multicolumn{2}{|c|}{ open } & \multicolumn{2}{|c|}{ dryer } & \multicolumn{2}{|c|}{ open } & \multirow[t]{2}{*}{$\min$} & \multirow[t]{2}{*}{$\max$} \\
\hline & $\min$ & $\max$ & $\min$ & $\max$ & $\min$ & $\max$ & $\min$ & $\max$ & & \\
\hline Day 1 & 28 & 32 & 29 & 32 & 61 & 80 & 73 & 93 & 126 & 284 \\
\hline Day 2 & 36 & 47 & 32.5 & 40 & 49 & 77 & 57 & 77 & 191 & 434 \\
\hline Day 3 & 35 & 46 & 35 & 44 & 48 & 84 & 50 & 93 & 411 & 773 \\
\hline Day 4 & 37 & 45 & 36 & 42 & 44 & 76 & 49 & 87 & 419 & 606 \\
\hline
\end{tabular}


Table.3 Proximate and biochemical characteristics of dried Anchovy (S. commersonii)

\begin{tabular}{|l|c|c|c|c|c|c|c|}
\hline Drying methods & $\begin{array}{c}\text { Moisture } \\
(\boldsymbol{\%})\end{array}$ & $\begin{array}{c}\text { Crude } \\
\text { protein (\%) }\end{array}$ & $\begin{array}{c}\text { Crude } \\
\text { fat }(\mathbf{\%})\end{array}$ & Ash (\%) & $\begin{array}{c}\text { FFA (\% } \\
\text { Oleic acid) }\end{array}$ & $\begin{array}{c}\text { PV (meq } \\
\text { O2/kg fat) }\end{array}$ & $\begin{array}{c}\text { TVBN } \\
(\mathbf{m g} \%)\end{array}$ \\
\hline Open sun dried & $34.43 \pm 0.32$ & $34.5 \pm 0.38$ & $3.22 \pm 0.48$ & $6.8 \pm 0.05$ & $1.43+0.15$ & $5.08+0.19$ & $76.29+1.31$ \\
\hline Solar rack dried & $28.89 \pm 0.31^{*}$ & $41.33 \pm 0.41^{*}$ & $4.31 \pm 0.14$ & $8.39 \pm 0.25^{*}$ & $1.59+0.03$ & $2.33+0.34^{*}$ & $50.92+0.91^{*}$ \\
\hline P value & $<0.0001$ & 0.0021 & 0.0621 & 0.0027 & 0.1362 & 0.0002 & $<0.0001$ \\
\hline
\end{tabular}

Fig.1 Low cost solar dryer

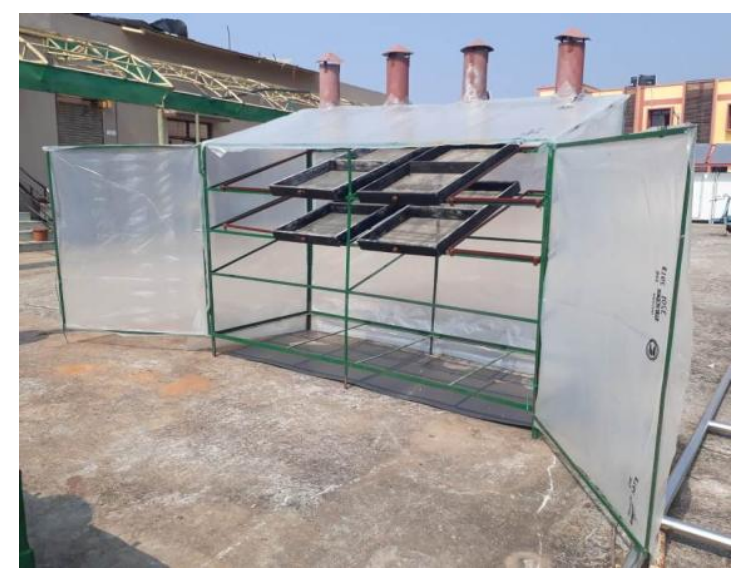

Fig.2 Drying rate of anchovy (S.commersonii) in solar rack dryer and open sun

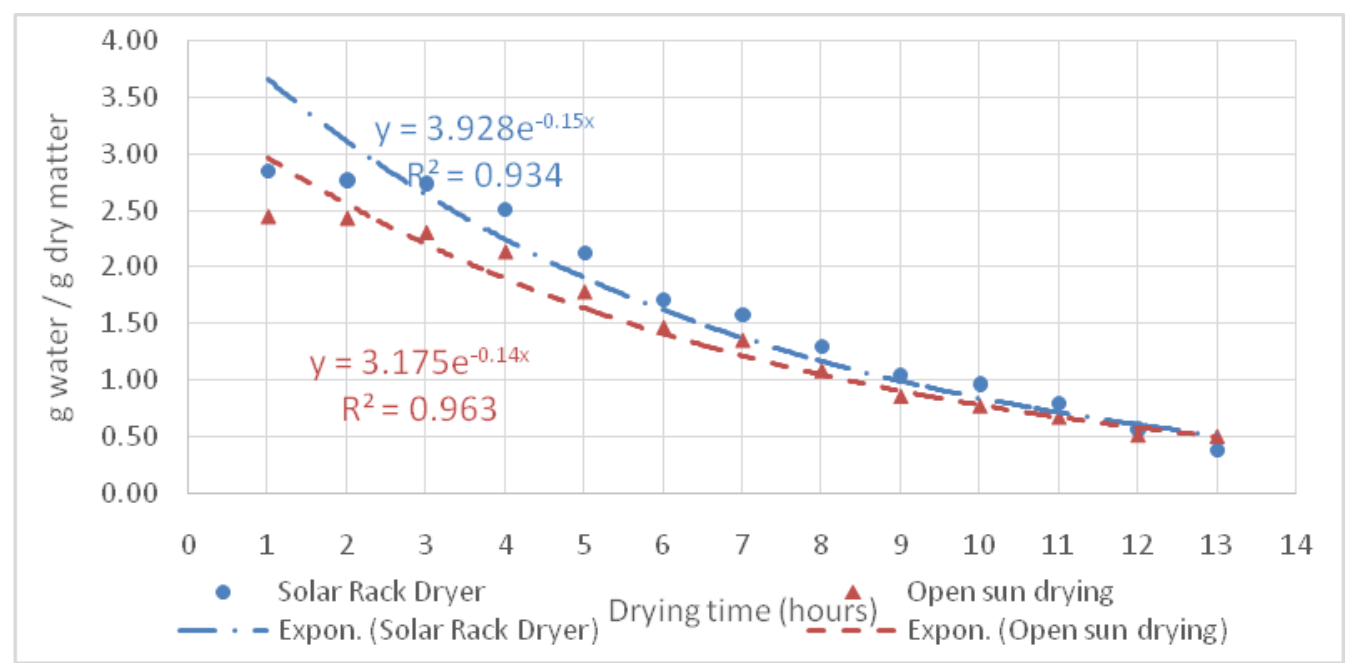

A rancid taste often becomes noticeable at peroxide value of 10-20\% (Oparaku et al., 2010; Enamul et al., 2013). The open dried fish had a significantly higher highest peroxide value probably due to the uninhibited exposure to sun. The peroxide value in both solar dried and sun dried anchovies was lower than the recommended value of $20 \mathrm{meq} / \mathrm{kg}$ oil (Table 3 ).

Free fatty acids are formed through chemical or enzyme linked hydrolysis of 
triacylglycerides and it indicates the post mortem degradation of fish. The free fatty acids are further oxidized to produce secondary oxidation products, which causes rancidity of fish and fishery products (Toyamizu et al., 1981). Generally, lower acid values indicate better quality of a product. In this study, the average free fatty acid values were 1.43 and $1.59 \%$ oleic acid of lipid in solar dried and open dried anchovies respectively (Table 3) which is much less than reported by many authors in dried fish (Majumdar et al., 2017; Razul et a.l, 2018). This could be due to the reduced activity of fish muscle enzyme and microorganisms because of the removal of moisture from fish by drying.

Hence it can be concluded that by achieving increased drying temperatures and reduced relative humidity, the low cost natural convection solar rack dryers can comparatively increase the drying rate to produce a product with low moisture content and improved quality compared with the traditional open sun drying method. This improvement in terms of quality can help the fisherwomen get better prices for their fish and enhance the preferences of consumers.

\section{Acknowledgement}

The authors are thankful to ICAR, New Delhi for financial support, Director ICAR-CIWA for providing all necessary facilities.

\section{References}

Abraha, B., Samuel, M., Mohammud, A., Habte-Tsion, H.M., Admassu, H.,. AlHajj, N.Q.M. (2017). A comparative study on quality of dried anchovy (stelophorus heterolobus) using open sun rack and solar tent drying methods. Turkish Journal of Fisheries and Aquatic Sciences, 17:1107-1115.
AOAC. (2000). Official methods of analysis (17th Edn.), Association of Official Analytical Chemists, Washington DC, USA.

Cho, J.H., Min, B.J., Chen, Y.J., Yoo, Y.S., Wang, Q., Kim, J.D. and Kim, I.H. (2007). Evaluation of FSP (fermented soy protein) to replace soybean meal in weaned pigs: growth performance, blood urea nitrogen and total protein concentrations in serum and nutrient digestibility. Asian Australian J. Anim. Sci., 20:1874-1879

Connell JJ. (1975). Methods for assessing and selecting for quality. Control of Fish Quality. Fishing News Books Ltd., England, pp.107-132.

Conway, E. J. (1950). Microdiffusion analysis and volumetric error (3rd Edn.), Lockwood and Son Ltd., Crosby, London, pp. 306.

Dagne, T., Guya, M., Abera, S. and Bekele, F. G. (2016). Effect of drying methods and pretreatments on nutritional value and sensory quality of fish (Oreochromis niloticus, Pylodictis olivaris and Cyprinus carpio) species commonly used in gambella region. Turkish Journal of Agriculture - Food Science and Technology, 4(1): 22-30.

Francisca, O.N., Obialo, M.B. and Effiong, E.J. (2010). Proximate and organoleptic characteristics of sun and solar dried fish. Animal Research International, 7(2): $1169-1175$.

Haque, E., Kamruzzaman, M., Islam, M.D., Sarwar, T., Rahman, S.S. and Karim. M.R. (2013). Assessment and comparison of quality of solar tunnel dried Bombay duck and Silver pomfret with traditional sun dried samples. International Journal of Nutrition and Food Sciences, 2(4): 187-195.

Hasan, M.M., Shikha, F.H., Hossain, M.I., Kamal, M., Islam, M.N. and Wahab, M.A. Quality assessments of traditional, 
rotary and solar tunnel dried small indigenous fish products. Bangladesh Journal of Fisheries Research, 10: 73-84. Immaculate, J., Sinduja, P. and Jamila, P. (2012). Biochemical and microbial qualities of Sardinella fimbriata sun dried in different methods. International Food Research Journal, 19: 1699-1703.

Jain, D. and Pathare, P.B. (2007). Study of drying kinetics of open sun drying of fish, Journal of Food Engineering, 78: 13151319.

Majumdar, B.C., Afrin, F., Rasul, M.G., Khan, M. And Shah, A.K.M.A. (2017). Comparative study of physico-chemical, microbiological and sensory aspects of some sun dried fishes in Bangladesh. Brazilian Journal of Biological Sciences, 4: 323-331.

Rasul, M.G., Majumdar, B.C., Afrin, F., Bapary, M.A.J. and Shah, A.A. (2018). Biochemical, Microbiological, and Sensory Properties of Dried Silver Carp (Hypophthalmichthys molitrix) Influenced by Various Drying Methods. Fishes, 3: 25-30

Relekar, S. S., Joshi, S. A., Gore, S. B. and Kulkarni A. K. (2014). Effect of improved drying methods on biochemical and microbiological quality of dried small head ribbon fish, Lepturacanthus savala International. Journal of Fisheries and Aquatic Studies, 1(5): 60-66.

Reza, S., Bapary, A. B. U. J. and Islam, N. (2009). Optimization of marine fish drying using solar tunnel dryer. Journal of Food Processing and Preservation, 33: 47-59.
Sankar, T. V., Anandan, R., Mathew, S., Asha, K.K. Lakshmanan, P.T, Varkey, J., Aneesh, P.A. and Mohanty, B. P. (2013). Chemical composition and nutritional value of Anchovy (Stolephorus commersonii) caught from Kerala coast, India. European Journal of Experimental Biology, 3(1):85-89.

Seveda, M.S. and Jhajharia, D. (2012). Design and performance evaluation of solar dryer for drying of large cardamom (Amomum subulatum). Journal of Renewable and Sustainable Energy, 4: 0631292-11.

Shah, A. K. M. A., Tokunaga, C., Kurihara, H. And Takahashi, K. (2009) Changes in lipids and their contribution to the taste of Migaki-nishin (dried herring fillet) during drying. Food Chemistry, 115 (3): 10111018

Shrivastava, K. P. and Anandavally, N. (1974). Studies on the changes in dried shrimp during long storage at normal room temperature. Seafood Export Journal, 6: 9-11.

Toyomizu, M., Hanaoka, K. and Yamaguchi, K. (1981). Effect of release of free fatty acids by enzymatic hydrolysis of phospholipids on lipid oxidation during storage of fish muscle at $-5 \circ \mathrm{C}$. Bulletin of the Japanese Society for the Science of Fish, 47: 605-610.

Yildiz, G., Wehling, R. and Cuppett, S.L. (2003). Comparison of four analytical methods for the determination of peroxide value in oxidized soybean oils. Journal of the American Oil Chemists Society, 80: 103-107.

\section{How to cite this article:}

Tanuja, S., C. S. Mhatre, G. Mohanty, E. Rout, P. Rout and Srivastava, S. K. 2020. Development of Low Cost Solar Rack Dryer and Comparative Biochemical Quality Evaluation of Anchovies (Stolephorus commersonii) Dried in Sun and Solar Rack Dryer. Int.J.Curr.Microbiol.App.Sci. 9(03): 579-586. doi: https://doi.org/10.20546/ijcmas.2020.903.068 